\title{
PROMOTING PERFORMANCE OF SMES ARCHITECTURAL FIRMS IN IMO STATE THROUGH APPLICATION OF COST ACCOUNTING SKILLS
}

\author{
Miriam Ijeoma Chukwuma-Uchegbu ${ }^{1} \bowtie(D)$, Vivian Anuli Enyeribe ${ }^{2} \square$, T.C. Okoro ${ }^{3}$, Chigozie James \\ Okereke $^{4}$ \\ ${ }^{4}$ Federal University of Technology Owerri, Imo State, Nigeria \\ ${ }^{2,3}$ Accountancy Department Alvan Ikoku Federal College of Education Owerri, Imo State, Nigeria
}

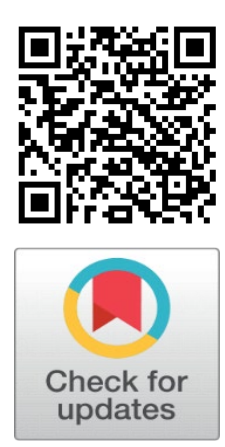

Received 25 July 2021

Accepted 7 August2021

Published 31 August 2021

\section{CorrespondingAuthor}

Miriam Ijeoma Chukwuma-Uchegbu, mimchuks@gmail.com

DOI

10.29121/granthaalayah.v9.i8.2021. 4146

Funding: This research received no specific grant from any funding agency in the public, commercial, or not-for-profit sectors.

Copyright: (C) 2021 The Author(s). This is an open access article distributed under the terms of the Creative Commons Attribution License, which permits unrestricted use, distribution, and reproduction in any medium, provided the original author and source are credited.

\section{ABSTRACT}

This study investigated effects of cost accounting skills on performance of small and medium scale architectural firms in Imo state. Specifically, the study appraises cost accounting skills applied in contract costing and also relationship between efficient financial record keeping and financial performance of architectural firms in Imo state, two hypotheses were developed from the objectives. The population consists of owners of 50 architectural firms in Owerri metropolis, which also served as sample. Primary data was used with questionnaire structured in four-point likert scale of very great extent (VGE), great extent (GE), very little extent (VLE) and little extent (LE). Cronbach Alpha reliability test was used to determine internal consistency of respondent's responses and reliability co-efficient of 0.796 . Data were analysed with ordinary least square regression model with SPSS stastitical tool version 20. Findings reveal that SMEs architectural firms ... null hypothesis one was accepted with conclusion that SME architectural firms do not practice cost accounting skill in contract costing while null hypothesis two was rejected with conclusion that significant relationship exist between efficient financial record keeping and financial performance of the firms. The research therefore recommends that; architectural firms should apply cost accounting skills in their contract costing and also keep efficient financial record to enhance their performance.

Keywords: Accounting Skills, Architectural Firm, Small and Medium Scale Enterprise

\section{INTRODUCTION}

A dynamic small scale enterprise sub-sector is important and imperative for the overall economic development in Nigeria. Indeed, unemployment has continued to cause social, economic and political problem among others, and there is therefore need for self-employment to be encouraged through entrepreneurship, as it is the most viable option in tackling the menace of unemployment in our society.

The word entrepreneurship originated from the twelfth-century French word entrependre meaning to undertake or do something. It is not a new phenomenon in Nigeria. Gana (2001) defined entrepreneurship as the willingness and the ability of an individual of an individual to seek out investment opportunities in an environment and be able to establish and run an enterprise effectively. Entrepreneurship as stated by Obi (2005) is the act inherent in someone in a venture or idea and assumes significant accountability of the risk involved. In a sense entrepreneurs can shape the needs and desire of customers 
and transform raw materials in a way that changes and shape reality through the knowledge and possession of basic accounting skills.

Skills according to Osimen (2008), is the ability to do something well. It refers to the abililty to perform an act expertly. It is the exactness practiced ability displayed in doing a task. Therefore, accounting skills and strategies can help entrepreneurs in realizing their objectives, because it gives analytical tools to make projections and link what is expected to happen in the real world with the value added by our efforts.

Uchegbu (2008) defined accounting as the art of controlling a business by keeping accurate booking records, and preparing from the records, certain financial difficulties called accounting ratio and using these ratios to deduct financial difficulties before they become serious, so that counter measures may be taken. Accounting also can be seen by Osuala (2005) as a language which all business decision makers must understand. He further submits that it is a process that encompasses capturing, processing and communication of financial information. Daniju (2007) is of the opinion that finance and skill acquisition which cut across all ages forms the key to empowerment of small and medium scale enterprises.

Small scale business, small scale industries and small-scale entrepreneurs are used interchangeably to mean a small-scale industry firm. There seems to be no specific definition of small business. Different authors, scholars and schools have different ideas as to the meaning of small-scale industry. Ogundele (2007) defined SMEs as one who has a minimum of 5 employees with minimum capital outlay of not less than 5naira. In the same vein, Chukwuemeka (2004) sees small and medium scale business as one whose total asset in capital equipment, plant and working capital are less than 250naira and employing fewer than 50 full time workers.

Nigeria council for industries (2003) defined small and medium scale enterprise as an enterprise with an asset base ranging from between 1.5 million and 200 million naira including working capital but excluding cost of land and must have a workforce of eleven to three hundred workers. However, SMEs are believed to be the engine room for the development of any economy because they form the bulk of business activities in a growing economy like that of Nigeria. According to Mukaila (2011), small and medium scale enterprise contributes to improved living standards, bring about substantial local capital formation, achieve high level of productivity and the creation of jobs at relatively low capital cost. However, despite the numerous contributions and advantages small and medium scale enterprise holds for the development of the Nigerian economy, they are bedeviled by numerous challenges which have hampered its development, growth and contribution to national development especially in Imo state.

This is seen where many small businesses die within their first year of existence. Statistics has it that about $50 \%$ of business established die within first year while $20 \%$ or $30 \%$ die within the next 5 years and only $20 \%$ survives strives and grow to maturity. Most of the reason behind this failure includes the neglect of accounting and book-keeping skills and techniques by most entrepreneurs. Such skills include but not limited to financial managerial skill, recording keeping skill, marketing skill, human resources, skills in purchasing and supply, simple budgeting and tax evaluation among others. These accounting skills are needed by the entrepreneurs to measure their business success, reassess their progress and change directions when necessary. Again, most small-scale firms lack the capacity, the skills and proficiency to prepare accounts and returns to meet the requirements 
of tax authorities. There is therefore need to evaluate the extent small and medium scale firms' use accounting skills in Imo state.

According to Onoh (2011) fundamental accounting skill are those competencies in basic accounting required by an individual to perform competently, confidently and successfully in daily business transactions. They include skill in book-keeping, purchasing and supply, bargaining, determining labour cost, simple budgeting, keeping of accurate receipts and payments, sales record skills, work in progress records, prudent financial and working management and skills needed for accounting for store and materials among others.

In addition, Osuala (2005) also contributed that the knowledge of fundamental accounting skills is very imperative for sustainable business. The non-possession of these fundamental accounting skills by SMEs, especially architectural firms therefore, constitutes a problem such that the chances of survival of the business are slim and the probabilities of collapse become high. Hence every small and medium scale enterprises should strive to acquire and possess these cost accounting skills.

Therefore, the acquisition of these accounting skills by architectural SME owners and managers is important, as it will imbue on them the needed contract costing skill as well as skills necessary in keeping good financial record to effectively manage their businesses in the most profitable way in other to achieve maximum return on capital invested. Thus, this paper set out to investigate effects of cost accounting skills on performance of small and medium scale firms in Imo state

\section{RESEARCH HYPOTHESES}

The following hypotheses were formulated to guide the study.

1) There is no significant relationship between architectural SMEs keeping of efficient financial record and its performance in Imo state.

2) Owners and operators of architectural SMEs in Imo state do not possess cost accounting skills for contract costing to improve performance.

Several studies related to the present study have been carried out although none led emphasis on the purpose and area of the present study, such studies like Ogbo (2012) Examined the role of entrepreneurship in economic development in Nigeria. In his study, 100 SMEs were randomly analyzed using SPSS, hypotheses tested at 0.05 level of significance using chi square statistics which hinges on identifying the greatest problems of SMEs in Nigeria and the relationship between the form and nature of the business enterprises and its sources of funding for its operation. Findings revealed that SMEs have played and continue to play significant role in the growth, development and industrialization $w$ of many economies in the world. In the case of Nigeria SMEs have performed below expectation due to a combination of sever problems. It was then recommended that promoters of SMEs should thus ensure the availability or possession of managerial capacity and acumen before pursuing financial resources.

In a related development Iloh (2009) researched on the impact of small-scale enterprises financing in improving the socio-economic wellbeing of delta state. The study explores the impact of SMEs in developing countries. The method used for gathering data was primary and secondary sources of data. The work revealed that SMEs is the foundation and strength of any economy and therefore concluded that 
SMEs facilitates sustainable growth and development. Furthermore, Ekwe and Abuka (2014) worked on accounting skills for sustainable development of SMEs in the state and to determine the benefits accruable to the firms who acquire these skills. The study adopted a descriptive research design and data were generated through a thirty-point structured questionnaire and was analyzed using mean score and standard deviation of the respondents. The hypotheses were tested using t-test statistics.

The results showed that most of the owners and operators of SMEs in the state do not know accounting skills required enhancing the economic status of their business and it was recommended that there should be massive and regular training of the owners and operators of SMEs nationwide on accounting and business skills. Nwaigburu and Eneogwe (2013) also researched on the impact of accounting skill on entrepreneurship education for self-reliance and sustainable development in owerri municipal council of Imo state. The purpose of the study is to determine how accounting skills can improve entrepreneurship in Nigeria. One research question and two hypotheses were formulated to guide the study, survey research design was adopted in the study, data was collected using primary source and later analyzed with the use of chi-square. They concluded that accounting skill are highly contributory to entrepreneurship performances and is therefore required to be possessed by owners of SMEs in owerri municipal council of Imo state

\section{THEORETICAL FRAMEWORK}

\subsection{THE DOUBLE ENTRY THEORY}

This theory was propounded by an Italian monk rev. Father Lucca Pacioli $\mathrm{n}$ 1494 , he postulated that all entries must have a double entry. The theory states that "To every debit entry there must be a corresponding credit entry or vice versa". The debit entry receives value while the credit entry gives value. This work is related and also hinged on this theory by advising that the preparation of accounting and booking records by accountants/managers in SMEs should be done using the theory of double entry system. Double entry should not be neglected or else, it will affect accounting and thereby give false statement of the firm's account. Double entry system helps to determine when there is misappropriation of figures in balancing the accounts. So, if the account records are not properly done using double entry it could bring a negative effect on the management of small and medium scale firms.

\subsection{METHODOLOGY}

The study was conducted using survey research design. Survey research design was suitable for the study because according to Osuala (2005) survey design involves the collection of detailed description of public opinion on existing phenomena with the intent to justify current conditions and practices to make better plans for improving phenomena. The study was carried out in owerri metropolis of Imo state. The population consists of owners of 50 architectural firms in owerri metropolis, which also served as sample. Primary data was used with questionnaire structured in four likert scale of very great extent (VGE), great extent (GE), very little extent (VLE) and little extent (LE). Cronbach Alpha reliability test was used to determine internal consistency of respondent's responses and reliability co-efficient of 0.796 . Data were analyzed with ordinary least square regression model with SPSS statistical tool version 20. 


\subsection{MODEL OF ESTIMATION}

An examination of the effect of variables, application of cost accounting skill in contract costing, efficient keeping of financial records on performance of architectural firms was tested using multiple regression analysis with SPSS stastitical package version 20 . The functional relationship in the model is represented as: performance $=\mathrm{f}(\mathrm{x} 1, \mathrm{x} 2)$

The multiple regression equation was estimated thus;

$\mathrm{Y}=\mathrm{x} 1+\mathrm{x} 2=\mathrm{u}$.

Where;

Y= Financial performance. (Dependent variable).

$\mathrm{X} 1$ = Application of cost accounting skill in contract costing (Independent variable).

$\mathrm{X} 2=$ Efficient keeping of financial records (Independent variable).

$\mathrm{U} 1=$ Error term.

\subsection{DATA PRESENTATION AND ANALYSIS}

In this section, data presentation analysis and interpretation of result was dealt on. The research employed ordinary least square regression model to examine the relationship between efficient financial record keeping and financial performance of architectural firms, represented as $\mathrm{x} 1$ in the model, and also to appraise application of cost accounting skill applicable by architectural firms in contract costing, represented as $\mathrm{x} 2$ in the model. The results are presented in Table 1 below.

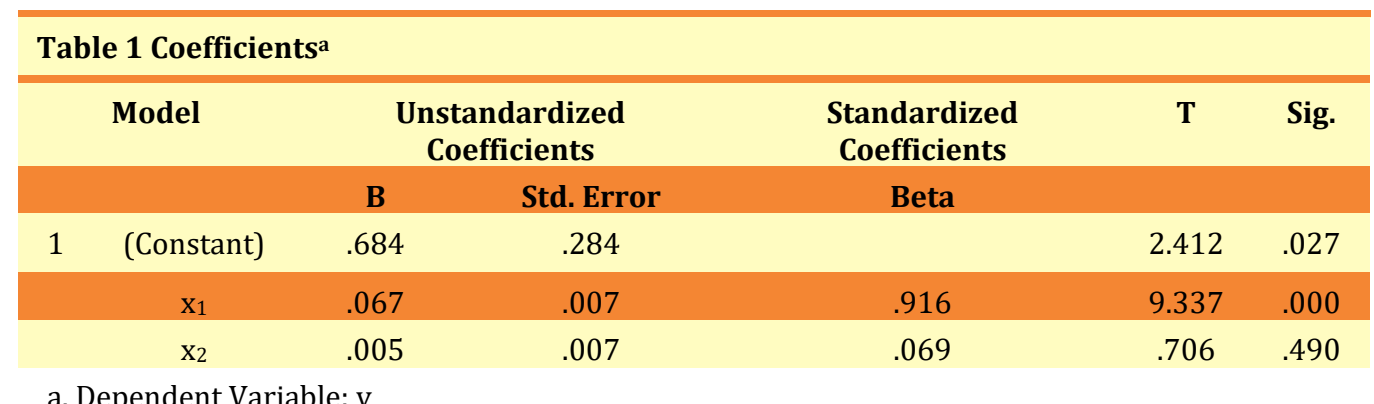

Adjusted R2 0.837

F- statistics .43 .608

observed level of significance. . .0 .00$

T statistics of $\mathrm{X}_{1}=9.337$ observed level of significance .0 .00

T statistics of $X_{2}=0.706$

observed level of significance .0 .490

Fitness of the model of OLS regression was carried out with $\mathrm{f}$ stastistics, 43.608 f statistic figure with significant probability value of 0.00 less than 0.05 level of significance shows that the model is fit and the variables captured in the model is significant in predicting performance of architectural firms. $0.873 \mathrm{R} 2$ value shows 
that a strong relationship of $83.7 \%$ exist between the variables captured in the study and performance of architectural firms. The model relationship is represented in this equation $\mathrm{Y}=0.684+0.067 \times 1+0.005 \times 2$. where $\mathrm{y}$ represents financial performance the dependent variable, $\mathrm{X} 1$ represents efficient financial record keeping and X2, cost accounting skill applicable by architectural firms.

Analysis of results showed that $\mathrm{t}$ statistics of $\mathrm{x} 1$ is 9.337 at observed level of significance 0.00 less than 0.05 alpha level of significant. We therefore reject the null hypothesis one and conclude that significant relationship exists between efficient financial record keeping and financial performance of architectural firms. Results further showed that $t$ stastistics of $x 2$ is 0.706 at observed level of significance 0.490 higher than 0.05 alpha level of significant we accept null hypothesis two with conclusion that owners of architectural firms in Imo state do not apply cost accounting skill for contract costing to improve performance.

\section{RECOMMENDATIONS}

Based on the findings, the study recommends that Architectural firms should;

- Apply cost accounting skills in their contract costing.

- Endeavor to keep efficient financial record to enhance their performance.

\section{CONCLUSION}

The research concludes that;

Significant relationship exists between efficient financial record keeping and financial performance of architectural firms.

Owners of architectural firms in Imo state do not apply cost accounting skill for contract costing to improve performance.

\section{REFERENCES}

Akande 0. 0. (2011). Accounting skills as a performance Actor for a small business in Nigeria, Journal of emerging trends in Economics and management studies JEMENS 0.2, (5) Oyo state.

Chukwuemeka, I.L (2004). Problem of financing small scale business in Nigeria. An MBA research publication, University of Nigeria Nsukka.

Daniju, A (2007) Skills Acquisition, key 10 grassroots Empowerment. This day Wednesday, July 11th P , 34.

Gana, J.S.S (2001). Entrepreneurship. Nsukka Nigeria: Great express publishers Ltd

Obi, C.I (2005) Identification of the entrepreneurial traits possessed by senior secondary school students in Adamawa state. The Nigeria Academic forum, vol 9 No 3 Awka.

Osimen, E.C (2008) Managing Agricultural Education and training: resources, principles and methods. Enugu Belony International Publishers.

Osuala. E.C(2005). Introduction to research methodology. The Millennium Education, Enugu Nigeria: CHESTON Agency limited 
Osula E.C (2000). Business management owerri: Cape publisher international limited.

Uchegbu B.C (2008) Modern Approach to basic financial Accounting principles and practice, Owerri: CEL-BEZ and CO publishers. 